\title{
Effect of Natural Food Components to Reduce the Risk of Obesity: A Review
}

\author{
Piyush Limbachiya, Jayesh Kabariya, Dr. Tanmay Hazra and Dr. Vimal Ramani* \\ College of Dairy Science \& Postgraduate Institute of Dairy Education and Research, \\ Kamdhenu University, Amreli, Gujarat-365601, India
}

*Corresponding author

\begin{tabular}{l} 
K e y w o r d s \\
$\begin{array}{l}\text { Nutritional factors, } \\
\text { Obesity, Functional } \\
\text { foods, Appetite, } \\
\text { Bioavailability }\end{array}$ \\
\hline Article Info \\
$\begin{array}{l}\text { Accepted: } \\
\text { 24 August } 2019 \\
\text { Available Online: } \\
\text { 10 September } 2019\end{array}$ \\
\hline
\end{tabular}

\section{A B S T R A C T}

The role of nutritional factors or dietary elements is much more important which comprise balancing of energy between energy expenditure and intake or other factors that contribute to prevent obesity. Obesity is a noteworthy public health issue whose incidence tends to increase continuously. Emerging scientific data over the previous decade recommends that dairy foods might be advantageous when incorporated into a moderate energy limited diet and perhaps for weight management too. The improvement in functional foods used for the prevention and treatment of obesity assume an opportune time for the food market in addition to include the knowledge regarding mechanisms of energy expenditure and appetite as well as metabolic sensation of satiety. There are different natural product combinations that may affect in a synergistic movement which enhance their bioavailability plus action on several molecular targets, generating advantages in excess of chemical treatments. Various natural food components used in functional foods that give anti-obesity effect may include bioactive fatty acids, phenolic compounds, protein, phytochemicals, dietary calcium and dietary fiber.

\section{Introduction}

Obesity is one of the major health issue seen in people worldwide, and it is widely accepted as a risk factor for several non-communicable such as, diabetes (Type 2), cardiovascular diseases and some cancers. The definition of obesity is given by World Health Organization (WHO) which is described as abnormal or excessive fat accumulation that may harmful for health. It is depend upon person's body mass index (BMI) and waist to hip circumference ratio in which BMI is defined as the weight in kilograms divided by the height in meter squared $\left(\mathrm{kg} / \mathrm{m}^{2}\right)$. This is an index that generally used to classify obesity and overweight in human due to its simplicity and easy to calculate. The value of BMI of 30 or more is normally considered as obese and BMI equivalent to or more than 25 is 
considered overweight. It has been observed that in the previous 40 years, the incidence of obesity almost tripled and around 650 million people in the world, together with number of children and infants were obese in 2016 (WHO, 2018). It is primarily happen either due to insufficient physical activity or excess calorie intake or sometimes both. Furthermore, genetic, behavioral and also environmental factors contribute to initiate the obesity (James, 2008). As societies become progressively more dependent on energydense, big-portions and fast-food meals, the connection between fast-food utilization and obesity becomes additional concerning (Rosenheck, 2008).

Vincent and le Roux (2007) suggested that because of the multifaceted nature of obesity, there is no single or simple solution to combat this growing epidemic. Novel and most probably individualized interventions may be required to effectively treat and prevent obesity.

The best approach to address the epidemic of obesity is to understand the underlying mechanisms of appetite control, applying this knowledge to develop functional ingredients that can promote more significant weight loss and appear to be a promising idea to combat obesity in future. Some of the research studies have shown the beneficial health effects of consuming dairy products (i.e., fermented milks, yoghurt) on metabolic hazardous factors in obese individuals (Gonzalez et al., 2012).

Pe'russe and Bouchard detailed that (2000) nutritional genomics could find out which specific nutrients convey phenotypic changes that impact on the risk of obesity and could set up an idea about which connections are the more significant for it. From dietary components, gut bacteria ferment indigestible carbohydrates, synthesized amino acids and
SCFAs (short chain fatty acids) that may probably contribute to provide the energy to the host (Nieuwdorp et al., 2014; Backhed et al., 2005). On the other side, modulated gut microbiota subjects with obesity appear to be more capable for the energy harvesting from the diet and may be contribute to decrease extra weight gain (Turnbaugh et al., 2006).

Functional foods have been developed for weight control which involves the knowledge regarding body weight management system. Serrano and S'anchez-Gonzalez (2008) reported the most important strategies for weight management by incorporating different functional ingredients such strategies include stimulate energy expenditure (EE), food intake inhibition (by orexigenic signals inhibition or anorexigenic signals enhancement), limitation of bioavailability of nutrients (by digestive enzymes suppression) as well as modification of gut microbiota composition.

As per data shown in Table 1, scientists have studied the effect of natural food components (i.e., dietary fiber, calcium, fatty acids, plant sterols, soy protein) on body weight and obesity with their different mechanisms in both human and animals.

Such mechanisms include increasing fecal fat excretion, regulating adipocyte metabolism and TAG storage, regulating UCP2 expression, reducing LPL activity and increasing enzymes associates with $\beta$ oxidation of lipids, activating AMPK enzyme and phosphorilating hypothalamic STAT3, increase satiety through increase in circulating appetite regulatory hormones (e.g. GLP-1, CCK, PYY, GIP and insulin) that lead to reduce food intake, interfering with intestinal fatty acid absorption and some other mechanisms also with effective approach on decreasing food intake and enhancing satiety that reduce obesity level in both animals and human in addition to effectively prevent CVD. 


\section{Different natural food components used as anti-obesity agents}

\section{Calcium}

It is one of the most significant dairy and food products components that may be related to obesity. Although reviews reported that ingestion of dietary calcium may lead to weight reduction (Dougkas et al., 2011).

It is helpful in favor of the maintenance of blood calcium level, skeletal integrity in addition to decrease the risk of chronic diseases.

Some studies have recommended that a more ingestion of calcium might be increase emission of fecal fat and energy expenditure. The mechanism of expanding fecal fat emission is the most probably because of the development of unsolvable calcium-fatty acid soaps along with binding of bile acids (Bendtsen et al., 2013).

Second mechanism reported (Shi et al., 2001; Zemel et al., 2000; Zemel, 2005) for intracellular $\mathrm{Ca}^{2+}$ in the regulation of adipocyte metabolism and TAG storage. It proposed that high measure of dietary calcium may possibly adjust circulating calcitriol levels.

Thus, suppression of calcitriol through high calcium diets decreased adipocyte intracellular $\mathrm{Ca}^{2+}$, fatty acid synthesis, increased lipolytic activity and decreased adiposity (Trigueros et al., 2013; Zemel, 2002).

Another mechanism explained the anti-obesity action of calcium that associated with the decreased calcitriol followed by calcium intake. This decreased calcitriol stimulate UCP2 expression, which thusly improved apoptosis of adipocytes (Sun and Zemel, 2004).

\section{Protein}

Protein is better and more satiating macronutrient than carbohydrate and also connected with a diet-induced thermogenesis. The dairy proteins mainly whey protein (WP) is noted to be more satiating than other protein source (casein and soy protein) and it may improve satiety via increases the circulating appetite regulatory hormones comprising GLP-1 (glucagon-like peptide-1).

Amino acids and bioactive peptides are generated from whey protein during digestion in gastrointestinal tract which increases the release of different hormones for example, cholecystokinin (CCK), peptide YY (PYY), gastric inhibitory polypeptide (GIP), GLP-1 and insulin that leads to reduced food intake and increased satiety. The effect of WP on satiety may be preferable due to the glycomacropeptide (GMP). There is a common consent that proteins moderate lipid absorption \& synthesis and also stimulating lipid excretion (Khoury et al., 2013).

A recent randomized controlled trial suggested that a combination of WP plus glucomannan (Glucomannan has important satiety effect following by gelification) has applied to decline in the craving to eat (decrease appetite) that is linked with enterohormonal modification (increase GLP-1) in spite of the low protein content $(8 \mathrm{~g})$ with glucomannan, which could decrease the speedy absorption of WP in relevance to the net forming throughout the gelification of the gastric condition (Sukkar et al., 2013).

According to Baer et al., (2011) the supplementation with whey protein concentrate (WPC) ( $\sim 56 \mathrm{~g} /$ day) for six months without any dietary consult resulted in considerably lower fat mass, body weight along with waist circumference in obese people. 


\section{Fatty acids}

\section{Short chain fatty acids (SCFAs)}

Obesity and amount of SCFAs in gut has direct relationship. These saturated aliphatic organic acids comprise of 1-6 carbons of which butyrate (C4), propionate (C3) and acetate $(\mathrm{C} 2)$ are the mainly abundant $(\geq 95 \%)$ (Cook and Sellin, 1998). All of the individual SCFAs affect health differently. For example, acetate acts as a forerunner for cholesterol synthesis and lipogenesis whereas propionate has been reported to reduce acetate absorption into cholesterol (Hellerstein et al., 1991).

Figure 1 represents the mechanism of effect of SCFAs in human. As per this mechanism, Canfora et al., (2015) reported that SCFAs play significant role in the synchronization of energy metabolism and homeostasis. They can interact with $G$ protein-coupled receptor (GPR) 41 and GPR 43, which are prompting an expansion in the intestinal emission of PYY and GLP-1 receptors that can enhance satiety (Hur and Lee, 2015).

In this mechanism, SCFAs are conveyed to the liver and changed over to triacylglycerol; these de novo synthesized lipids are saved in adipocytes and gut microbiota produce the circulating lipoprotein lipase (LPL)-inhibitor, Fiaf or Angptl4 (Backhed et al., 2007). This LPL plays a vital role in hydrolyzing triglycerides (TGs) and discharging fatty acids that transport into adipocytes.

SFAs are re-esterified into TGs that further uptake and storage of tryglycerols in adipose tissue (Parekh et al., 2014). A higher activity of the LPL clearly implies to higher storage of triacylglycerol and LPL enlarged within the adipose tissues of humans and rodents in obesity (Mattijssen et al., 2014).

For example, Propionate can expand FFAs uptake, perhaps by influencing the LPL inhibitor ANGPTL4.
Both acetate and propionate may also decrease intracellular lipolysis by means of diminished hormone-sensitized lipase phosphorylation by synergistic with the SCFAs receptor GPR43 (Canfora et al., 2015).

Furthermore, SCFAs appear to initiate AMP kinase in muscles, expanding insulin affectability, fatty acid oxidation as well as diminishing lipid growth (Plaza-Diaz et al., 2019).

\section{Pollyunsaturated fatty acids (PUFAs)}

The prospective anti-obesity property of PUFAs might be described by their functions in the given aspects such as, in lipid metabolism, balance between energy ingestion and energy expenditure as well as status of neuroendocrine system and adipocytes.

It has been reported that PUFAs may possibly decrease the activity of the key enzymes liable for lipid synthesis i.e., stearoyl-CoA desaturase- 1 and fatty acid synthase. Thus, they may keep away from entering adipocytes for lipogenesis and furthermore upgrade thermogenesis and lipid oxidation (Trigueros et al., 2013). Diets for bovines with PUF (n3) plus polyphenols can naturally enriched milk with polyphenols and PUFAs (Santos et al., 2016).

According to Santos et al., (2017), they observed that this type of enriched milk as a complement to obese rats which has resulted in enlarged muscle mass and decreased LDL (low-density lipoprotein) values. Thus, PUFArich milk and normal whole milk have exposed to be helpful in a regular metabolic condition whereas milk enriched/fortified with polyphenols and PUFAs enhance metabolic effects on obesity to reduce it.

\section{Dietary Fiber}

There are various types of dietary fiber like, 
cellulose, pectin, gum, soluble dietary fiber used in many anti-obesity products. In 1979, Heaton has found three mechanisms for action of dietary fiber that dietary fiber play crucial role to decrease energy intake and could act as a physiologic barrier. Such mechanisms include: (a) providing satiety and decreasing appetite; (b) food absorption inhibition in small intestine and (c) displacement of some other nutrients in the diet with dietary fiber. Several solvable dietary fibers (e.g., pectins, gums and B-glucans) become thicken while blending with liquids and it is beneficial on behalf of viscosity aspect because they are major benefactor to physiological sound effects in the small intestine. Expansion of viscosity may probably slow gastric emptying and holdup nutrient absorption. Moreover, Dietary fiber could be a fermentable substrate intended for the colon microbiota that supporting in the formation of SCFAs.

A lot of eventual studies have been highlighted that long-term utilization of fiberrich food has a negative connection by means of body weight gain (Astrup et al., 2010). Champagne et al., (2011) examined the effect of changes in diet on body weight reduction and management. The conclusion was that increment of vegetables, fruits and low-fat dairy products containing dietary fiber may help to decrease weight gain. According to RDA (recommended dietary allowances), $35 \mathrm{~g} /$ day of the dietary fiber is suggested or required for healthy adults.

\section{Phytochemicals}

Polyphenols are useful functional components that have anti-oxidant, anti-carcinogenic, antiviral and anti-bacterial properties. In the earlier period from two decades, polyphenols have been reported to comprise beneficial effective property against obesity. For example, they could maintain adipocyte metabolism to restrain the growth of adipose tissue (Baboota et al., 2013). Flavonoids, stilbenes and phenolic acids are the widespread polyphenols which are being used in the enhancement of various natural food products for weight management. Phytosterols, which encompass plant-derived sterols and stanols, are compounds structurally similar to cholesterol. They present in dense concentrations in vegetable oils (e.g. soybean oil, sunflower oil and corn). Plant stanols and sterols have been proved be able to block the immersion of intestinal fatty acid along with decreasing weight gain in animal study (Gupta et al., 2015).

The mechanisms concerned with phytochemicals on body weight include: (a) inhibition of propagation of precursor cells; (b) increase of apoptosis effect; (c) inhibition of pancreatic lipase activity and (d) increase in energy expenditure (Birari and Bhutani, 2007). Food products fortified with soybean are preferred as healthy food and also considered as significant part of the diet. Vij et al., (2011) studied the soy protein and genistein supplementation in soy yoghurt that can reduce LDL (low density lipoprotein) cholesterol, total cholesterol as well as TGs levels in the liver and serum of mice which helps to decrease obesity level.

\section{Conjugated Linoleic Acid (CLA)}

In 2010, Kennedy and colleagues have studied that the linkage between obesity and gut microbiota lies in the capability of Actinobacteria and Firmicutes to generate CLA. Production of CLA is regarding within the situation of obesity as it has many antiobesity effects such as, accumulated energy metabolism, lipolysis and energy expenditure as well as decreased lipogenesis and adipogenesis. 
Table.1 Some natural food components with their prospective anti-obesity effect

\begin{tabular}{|c|c|c|c|}
\hline Components & $\begin{array}{ll}\text { Effect } & \text { in } \\
\text { Human/Animals } & \\
\end{array}$ & Different mechanisms & References \\
\hline Dietary Calcium & $\begin{array}{l}\downarrow \text { Obesity in Human } \rightarrow ? \\
\downarrow \text { Obesity in animals }\end{array}$ & $\begin{array}{l}\text { Increasing } \text { fecal fat } \\
\text { excretion; regulating } \\
\text { adipocyte metabolism and } \\
\text { TAG storage; regulating } \\
\text { UCP2 expression. }\end{array}$ & $\begin{array}{l}\text { Zemel et al., 2000; Zemel, } \\
\text { 2002, 2005; Sun and Zemel, } \\
\text { 2004; Christensen et al., } \\
\text { 2009; Astrup et al., 2010; } \\
\text { Derbyshire, 2010. }\end{array}$ \\
\hline Dietary fiber & $\begin{array}{l}\downarrow \text { CVD } \\
\downarrow \text { Obesity } \rightarrow \text { mixed esults }\end{array}$ & $\begin{array}{l}\text { Acting as a physiologic } \\
\text { obstacle to energy intake; } \\
\text { promoting secretion of } \\
\text { anorexigenic peptides. }\end{array}$ & $\begin{array}{l}\text { Liese et al., 2005; Pereira } \\
\text { and Ludwig, 2001; } \\
\text { Murakami et al., 2007. }\end{array}$ \\
\hline CLA & $\begin{array}{l}\downarrow \text { Obesity in animals } \\
\downarrow \text { Obesity in humans } \rightarrow \\
\text { mixed results }\end{array}$ & $\begin{array}{l}\text { Reducing LPL activity and } \\
\text { increasing } \\
\text { associates with } \beta \text {-oxidation } \\
\text { of lipids. }\end{array}$ & $\begin{array}{l}\text { Azain et al., 2000; DeLany } \\
\text { and West, 2000; Thom et } \\
\text { al., 2001; Meadus et al., } \\
\text { 2002; Silveira et al., } 2007 \text {. }\end{array}$ \\
\hline PUFAs & $\begin{array}{l}\downarrow \text { Obesity- ? } \\
\downarrow \text { CVD }\end{array}$ & $\begin{array}{l}\text { Inhibiting key enzymes for } \\
\text { lipid synthesis, increasing } \\
\text { thermogenesis and } \\
\text { preventing lipogenesis }\end{array}$ & $\begin{array}{l}\text { Froyland et al., 1997; Guo } \\
\text { et al., 2005; Liu et al., 2005; } \\
\text { Buckley and Howe, 2009; } \\
\text { Melanson et al., 2009. }\end{array}$ \\
\hline Soy protein & $\begin{array}{l}\downarrow \text { CVD } \\
\downarrow \text { Obesity in animals }\end{array}$ & $\begin{array}{l}\text { Isoflavon } \rightarrow \text { modulating } \\
\text { selective estrogen receptor } \\
\text { activity. } \\
\text { Peptides } \rightarrow \text { activating } \\
\text { AMPK and phosphorilating } \\
\text { hypothalamic STAT3 }\end{array}$ & $\begin{array}{l}\text { Bhathena and Velasquez, } \\
\text { 2002; Munro et al., 2003; } \\
\text { Velasquez and Bathena, } \\
\text { 2007; Jang et al., 2008; } \\
\text { Cederroth and Nef, 2009. }\end{array}$ \\
\hline $\begin{array}{l}\text { Dairy Proteins } \\
\text { (Whey/ Casein) }\end{array}$ & $\begin{array}{l}\downarrow \text { FI and } \uparrow \text { satiety } \\
\downarrow \text { Obesity in humans }\end{array}$ & $\begin{array}{l}\text { Peptides } \rightarrow \text { enhance satiety } \\
\text { through } \\
\text { circulating } \\
\text { regulatory appetite } \\
\text { comprising GLP-1, CCK, } \\
\text { PYY, GIP and insulin lead } \\
\text { to reduce food intake }\end{array}$ & $\begin{array}{l}\text { Baer et al., 2011; Khoury et } \\
\text { al., 2013; Pal et al., } 2014 .\end{array}$ \\
\hline Plant sterols & $\begin{array}{l}\downarrow \text { Obesity in humans } \rightarrow ? \\
\downarrow \text { CVD } \\
\downarrow \text { Obesity in animals }\end{array}$ & $\begin{array}{l}\text { Interfering with intestinal } \\
\text { fatty acid absorption. }\end{array}$ & $\begin{array}{lrrr}\text { Suzuki et al., } & 2007 \text {; } \\
\text { Takeshita et } \text { al., } & \text { 2007; } \\
\text { Rideout } \text { et } & \text { al., } 2010 . & \end{array}$ \\
\hline
\end{tabular}

[Abbrev: TAG- triacylglycerol, UCP2- uncloping protein-2, CVD- cardiovascular diseases, CLA- conjugated linoleic acid, PUFAs- polyunsaturated fatty acids, AMPK- AMP-activated protein kinase, STAT3- signal transducers and activators of the transcription 3, FI- food intake, GLP1- glucagon-like peptide-1 , CCKcholecystokinin , PYY- peptide YY, GIP- gastric inhibitory polypeptide, LPL- lipoprotein lipase, $\downarrow=$ decrease, $\uparrow=$ increase, $?=$ possible] (Source: Trigueros et al., 2013) 
Table.2 Some examples of food products fortified with potential bio-active components

\begin{tabular}{|c|c|c|c|}
\hline Products & Sub-type & Bio-active components & References \\
\hline $\begin{array}{l}\text { Milk and Milk } \\
\text { based products }\end{array}$ & $\begin{array}{l}\text { Milk } \\
\text { Milk shake, Milk shake powder } \\
\text { Milk, Yoghurt, fermented milk } \\
\text { (Low fat) } \\
\text { Drinking yoghurt } \\
\text { Fermented Milk } \\
\text { Yoghurt } \\
\text { Yoghurt }\end{array}$ & $\begin{array}{l}\text { PUFAs } \\
\text { PUFAs } \\
\text { PS } \\
\text { PUFAs } \\
\text { Citrus fibers } \\
\text { Isoflavones } \\
\text { Green and black tea }\end{array}$ & $\begin{array}{l}\text { Let et al., 2005, 2007b; } \\
\text { Clifton et al., 2004; Hansel } \\
\text { et al., } 2007 \\
\text { Nielsen et al., 2009; } \\
\text { Sendra et al., 2008; Rossi } \\
\text { et al., 2008; Jim'enez et } \\
\text { al., 2008; Jaziri et al., } \\
2009\end{array}$ \\
\hline Juices & $\begin{array}{l}\text { Orange juice } \\
\text { Lemon juice }\end{array}$ & $\begin{array}{l}\text { PUFAs } \\
\text { Anthocyanins and } \\
\text { otherphenolics }\end{array}$ & $\begin{array}{l}\text { Lovegrove et al., 1997; } \\
\text { Gonz'alez-Molina et al., } \\
2008\end{array}$ \\
\hline $\begin{array}{l}\text { Bakery products } \\
\text { and Bread }\end{array}$ & $\begin{array}{l}\text { Bread, biscuits, cake } \\
\text { Bread, cereal } \\
\text { Bread } \\
\text { Bars }\end{array}$ & $\begin{array}{l}\text { PUFAs } \\
\text { PS } \\
\text { PUFAs } \\
\text { PUFAs }\end{array}$ & $\begin{array}{l}\text { Clifton } \text { et al., 2004; Yep et } \\
\text { al., 2002; Horn et al., } \\
2009 \text {; Nielsen } \\
\text { Jacobsen, } 2009\end{array}$ \\
\hline Fish & $\begin{array}{l}\text { Fish (heat-induced) gel } \\
\text { Minced fish product }\end{array}$ & $\begin{array}{l}\text { Inner pea fiber } \\
\text { Fiber }\end{array}$ & $\begin{array}{l}\text { Cardoso et al., 2007; } \\
\text { Cardoso et al., } 2010\end{array}$ \\
\hline Meat products & $\begin{array}{l}\text { Dry fermented turkey sausage } \\
\text { Pork sausages } \\
\text { Raw sausage } \\
\text { Dry-cured sausage }\end{array}$ & $\begin{array}{l}\text { Green tea extract } \\
\text { Green tea powder } \\
\text { SPI } \\
\text { Orange fiber }\end{array}$ & $\begin{array}{l}\text { Bozkurt, 2006; Choi et al., } \\
\text { 2003; Porcella et al., 2001; } \\
\text { Fern'andez-L'opez et } \\
\text { al.,2008 }\end{array}$ \\
\hline $\begin{array}{l}\text { Margarines and } \\
\text { spreads }\end{array}$ & $\begin{array}{l}\text { Spreadable fat } \\
\text { Filling for sandwich cookies } \\
\text { Low-fat spread }\end{array}$ & $\begin{array}{l}\text { PUFAs } \\
\text { PUFAs } \\
\text { PUFAs }\end{array}$ & $\begin{array}{l}\text { Kolanowsky et al., 2004; } \\
\text { Borneo et al., 2007; } \\
\text { Lovegrove } \text { et al., } 1997\end{array}$ \\
\hline
\end{tabular}

[Abbrev: PUFAs- polyunsaturated fatty acids, PS- plant sterols, SPI- soy protein isolate] (Sourse: Trigueros et al., 2013)

Fig.1 Potential biological effect of fatty acid oxidation in human (Source: Plaza-Diaz et al., 2019)

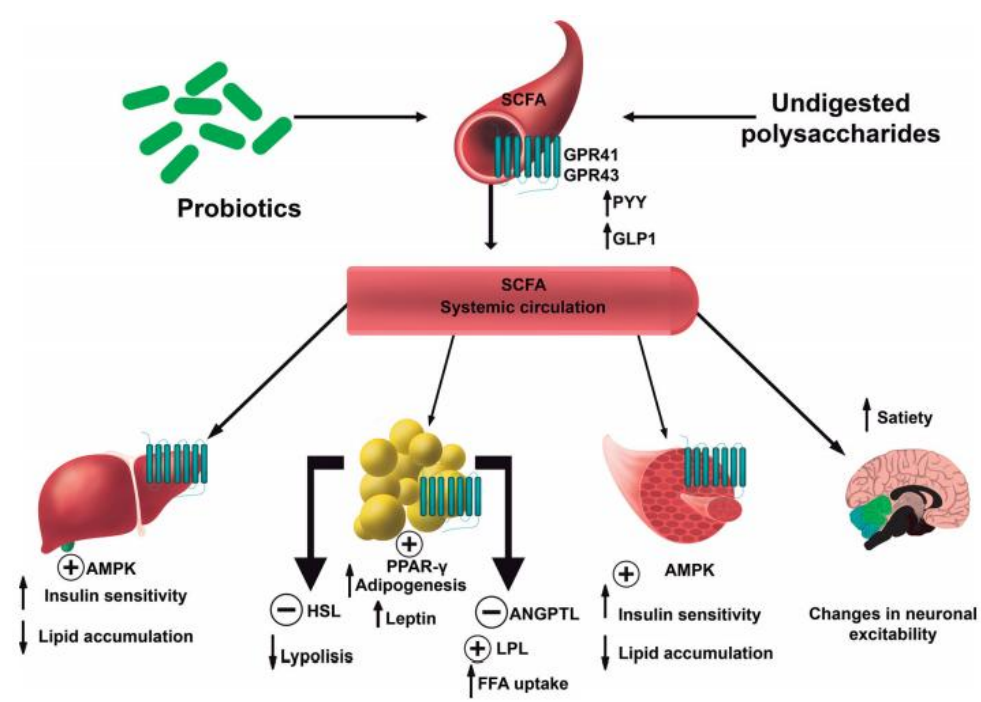


Additionally, some investigations have suggested that CLA has ability to decrease de novo lipid synthesis along with adipocyte apoptosis (Obsen et al., 2012).

It is observed that CLA mediates a number of effects by shifting arachidonic acid present in the phospholipids contained in cell membranes that diminishing the blend of eicosanoids like leukotrienes and prostaglandins well known factors in inflammation. Just as it has different signaling functions including activation of transcription factors and peroxisome proliferator-activated receptors (PPARs), which have downstream affected on lipid metabolism and immunity function (Belury, 2002). When study has been carried out on directed to mice, Mazloom et al., (2019) reported that CLA improved nervous system activity which led to enhance energy metabolism and reduce adipose tissue.

Table 2 summarizes some bioactive food ingredients which have been reviewed and reported by different scientists that natural food products (i.e., milk and milk based products, bakery products, marine products, meat products, several juices, margarines and spreads) fortified using potential anti-obesity ingredients (PUFAs, SPI, PS, fibers, isoflavones, green tea powder) have shown anti-obesity properties.

Obesity is one of the epidemic public health issues worldwide, affecting both developing and developed countries. One of the solution of this public health issue is medical treatment to diminish the level of it in obese patients by using drugs which are presently available in the market but limited in efficacy and also few in number and although several drugs have promising anti-obesity effects, there are numerous perspectives within this research field that require further exploration. Besides this mechanism, one of the recent approaches to resolve this epidemic health problem is utilization of natural foods that can play an effective and safe role especially those containing polyphenols, fibers, sterols and isoflavones in the prevention of obesity. Different potential activities of these natural products have been examined such as, regulate metabolism, fat absorption by the body, act as general body cleanser, energy booting and help in constipation, help to eliminate hunger during the treatment of obesity. Physiological, behavioral and environmental contributions all can be influence to initiate obesity.

\section{References}

Astrup, A., Kristensen, M., Gregersen, N., Belza, A., Lorenzen, J., Due, A. and Larsen, T. 2010. Can bioactive foods affect obesity? Annals of the New York Academy of Sciences, 1190: 25-41.

Azain, M., Hausman, D., Sisk, M., Flatt, W. and Jewel, D. 2000. Dietary conjugated linoleic acid reduces rat adipose tissue cell size rather than cell number. The Journal of Nutrition, 130: 1548-1554.

Baboota, R.K., Bishnoi, M., Ambalam, P., Kondepudi, K.K., Sarma. S.M., Boparai, R.K. and Podili, K. 2013. Functional food ingredients for the management of obesity and associated co-morbidities- A review. Journal of Functional Foods, 5: 997-1012.

Backhed, F., Ley, R., Sonnenburg, J., Peterson, D. and Gordon, J. 2005. Host-bacterial mutualism in the human intestine. Science, 307(5717): 1915-1920.

Backhed, F., Manchester, J.K., Semenkovich, C.F. and Gordon, J.I. 2007. Mechanisms underlying the resistance to diet-induced obesity in germ-free mice. Proceedings of the National Academy of Sciences of the United States of America, 104(3): 979984.

Baer, D.J., Stote, K.S., Paul, D.R., Harris, G.K., Rumpler, W.V. and Clevidence, B.A. 2011. Whey protein but not soy protein supplementation alters body weight and composition in free-living overweight and obese adults. Journal of nutrition, 141(8): 1489-1494. 
Belury, M. 2002. Dietary conjugated linoleic acid in health: Physiological effects and mechanisms of action. The Annual Review of Nutrition, 22: 505-531.

Bendtsen, L.Q., Lorenzen, J.K., Bendsen, N.T., Rasmussen, C. and Astrup, A. 2013. Effect of dairy proteins on appetite, energy expenditure, body weight, and composition: a review of the evidence from controlled clinical trials. Advances in nutrition, 4(4): 418-438.

Bhathena, S. and Velasquez, M. 2002. Beneficial role of dietary phytoestrogens in obesity and diabetes. The American Journal of Clinical Nutrition, 76: 1191-1201.

Birari, R.B. and Bhutani, K.K. 2007. Pancreatic lipase inhibitors from natural sources: Unexplored potential. Drug Discovery Today, 12: 879-889.

Borneo, R., Kocer, D., Ghai, G., Tepper, B.J. and Karwe, M.V. 2007. Stability and consumer acceptance of long-chain omega-3 fatty acids (eicosapentaenoic acid, 20:5, n-3 and docosahexaenoic acid, 22:6, n-3) in cream-filled sandwich cookies. Journal of Food Science, 72: S49-S54.

Bozkurt, H. 2006. Utilization of natural antioxidants: Green tea extract and Thymbra spicata oil in Turkish dryfermented sausage. Meat Science, 73: 442450.

Buckley, J. and Howe, P. 2009. Anti-obesity effects of long-chain omega-3 polyunsaturated fatty acids. Obesity Reviews, 10: 648-659.

Canfora, E.E., Jocken, J.W., Blaak, E.E. 2015. Short-chain fatty acids in control of body weight and insulin sensitivity. Nature Reviews Endocrinology, 11: 577-591.

Cardoso, C., Mendes, R. and Nunes, M. L. 2007. Dietary fibers effect on the textural properties of fish heat-induced gels. Journal of Aquatic Food Product Technology, 16: 19-30.

Cardoso, C., Mendes, R., Pedro, S., Vaz-Pires, P. and Nunes, M.L. 2010. Quality changes during storage of minced fish products containing dietary fiber and fortified with $\omega 3$ fatty acids. Food Science and Technology International, 16: 31-42.
Cederroth, C. and Nef, S. 2009. Soy, phytoestrogens and metabolism: A review. Molecular and Cellular Endocrinology, 304: 30-42.

Champagne, C.M., Broyles, S.T., Moran, L.D., Cash, K.C., Levy, E.J., Lin, P.H., Batch, B.C., Lien, L.F., Dalcin, A., Loria, C. and Myers, V.H. 2011. Dietary intakes associated with successful weight loss and maintenance during the Weight Loss Maintenance trial. Journal of the American Dietetic Association, 111(12): 1826-1835.

Choi, S.H., Kwon, H.C., An, D.J., Park, J.R. and Oh, D.H. 2003. Nitrite contents and storage properties of sausage added with green tea powder. Korean journal for food science of animal resources, 23: 299-308.

Christensen, R., Lorenzen, J., Svith, C., Bartels, E., Melanson, E., Saris, W., Tremblay, A. and Astrup, A. 2009. Effect of calcium from dairy and dietary supplements on faecal fat excretion: A meta-analysis of randomized controlled trials. Obesity Reviews, 10: 475-486.

Clifton, P.M., Noakes, M., Sullivan, D., Erichsen, N., Ross, D., Annison, G., Fassoulakis, A., Cehun, M. and Nestel, P. 2004. Cholesterol-lowering effects of plant sterol esters differ in milk, yoghurt, bread and cereal. European Journal of Clinical Nutrition, 58: 503-509.

Cook, S. and Sellin, J. 1998. Short chain fatty acids in health and disease. Alimentary pharmacology and therapeutics, 12(6): 499-507.

DeLany, J. and West, D. 2000. Changes in body composition with conjugated linoleic acid. Journal of the American College of Nutrition, 19: 487S-493S.

Derbyshire, E. 2010. Does adult calcium intake influence body composition? A review. Nutrition \& Food Science, 40(5): 494-503.

Dougkas, A., Reynolds, C.K., Givens, I.D., Elwood, P.C. and Minihane, A.M. 2011. Associations between dairy consumption and body weight: a review of the evidence and underlying mechanisms. Nutrition research reviews, 24(1): 72-95.

Fernandez- Lopez, J., Sendra, E., Sayas- Barbera, M. E., Navarro, C. and P'erez- Alvarez, J. 
A. 2008. Physicochemical and microbiological profiles of "Salchich'on" (Spanish dry-fermented sausage) enriched with orange fiber. Meat Science, 80: 410417.

Froyland, L., Madsen, L., Vaagenes, H., Totland, G. K., Auwerx, J., Kryui, H., Staels, B. and Berge, R. 1997. Mitochondrion is the principal target for nutritional and pharmacological control of triglyceride metabolism. The Journal of Lipid Research, 38: 1851-1858.

Gonzalez, M., Moreno, D.A. and Garc'ra-Viguera, C. 2008. Aronia-enriched lemon juice: A new highly antioxidant beverage. Journal of Agricultural and Food Chemistry, 56: 11327-11333.

Guo, W., Xie, W., Lei, T. and Hamilton, J. 2005. Eicosapentaenoic acid, but not oleic acid, stimulates beta-oxidation in adipocytes. Lipids, 40: 815-821.

Gupta, V.K., Tuohy, M.G., O’Donovan, A. and Lohani, M. 2015. Biotechnology of Bioactive Compounds: Sources and Applications. Wiley-Blackwell: Chichester, UK, pp. 565-581.

Hansel, B., Nicolle, C., Lalanne, F., Tondu, F., Lassel, T., Donazzolo, Y., Ferri`eres, J., Krempf, M., Schlienger, J.L., Verges, B., Chapman, M. J. and Bruckert, E. 2007. Effect of low-fat, fermented milk enriched with plant sterols on serum lipid profile and oxidative stress in moderate hypercholesterolemia. The American Journal of Clinical Nutrition, 86: 790-796.

Heaton, K. W. 1979. Fibre, satiety and insulin, a new approach to ovemutrition and obesity: in Heaton, K.W. (Ed.), Dietary Fibre: Current Developments of Importance to Health, Food and Nutrition Press, Westport, Connecticut, pp. 141-149.

Hellerstein, M.K., Christiansen, M., Kaempfer, S., Kletke, C., Wu, K., Reid, J.S., Mulligan, K., Hellerstein, N.S. and Shackleton, C.H. 1991. Measurement of de novo hepatic lipogenesis in humans using stable isotopes. Journal of Clinical Investigation, 87(5): 1841-1852.

Horn, A.F., Nielsen, N.S. and Jacobsen, C. 2009. Addition of caffeic acid, ascorbyl palmitate or $\gamma$-tocopherol to fish oil enriched energy bars affects lipid oxidation differently. Food Chemistry, 112: 412-420.

Hur, K. and Lee, M. 2015. Gut microbiota and metabolic disorders. Diabetes \& Metabolism Journal, 39: 198-203.

James, W. 2008. The fundamental drivers of the obesity epidemic. Obesity Reviews, 9(1): 6-13.

Jang, E., Moon, J., Ko, J., Ahn, C., Lee, H., Shin, J., Park, C. and Kang, J. 2008. Novel black soy peptides with anti-obesity effects: Activation of leptin-like signaling and AMP-activated protein kinase. International Journal of Obesity, 32: 1161-1170.

Jaziri, I., Ben Slama, M., Mhadhbi, H., Urdaci, M. C. and Hamdi, M. 2009. Effect of green and black tea (Camellia sinensis L.) on the characteristic microflora of yogurt during fermentation and refrigerated storage. Food Chemistry, 112(3): 614-620.

Kennedy, A., Martinez, K., Schmidt, S., Mandrup, S., La Point, K. and McIntosh, M. 2010. Antiobesity mechanisms of action of conjugated linoleic acid. The Journal of Nutritional Biochemistry, 21: 171-179.

Khoury, E.I., Anderson, D. and Harvey, G. 2013. Recent advances in dietary proteins and lipid metabolism. Current Opinion in Lipidology, 24(3): 207-213.

Kolanowski, W., Swiderski, F., Jaworska, D. and Berger, S. 2004. Stability, sensory quality, texture properties and nutritional value of fish oil-enriched spreadable fat. Journal of the Science of Food and Agriculture, 84: 2135-2141.

Let, M.B., Jacobsen, C., Pham, K.A. and Meyer, A.S. 2005. Protection against oxidation of fish oil enriched milk emulsions through addition of rapeseed oil or antioxidants. Journal of Agricultural and Food Chemistry, 53: 5429-5437.

Let, M.B., Jacobsen, C., Sørensen, A. D.M. and Meyer, A.S. 2007b. Homogenization conditions affect the oxidative stability of fish oil enriched milk emulsions: Lipid oxidation. Journal of Agricultural and Food Chemistry, 55: 1773-1780.

Liese, A., Schulz, M., Fang, F., Wolever, T., D’Agostino Jr., R., Sparks, K. and Mayer- 
Davis, E., 2005. Dietary glycemic index and glycemic load, carbohydrate and fiber intake, and measures of insulin sensitivity, secretion, and adiposity in the Insulin Resistance Atherosclerosis Study. Diabetes Care, 28: 2832-2838.

Liu, B., Kuo, C.,Wang, Y. and Ding, S. 2005. Effect of docosahexaenoicacid and arachidonic acid on the expression of adipocyte determination and differentiation-dependent factor 1 in differentiating porcine adipocytes. Journal of Animal Science, 83: 1516-1525.

Lovegrove, J.A., Brooks, C.N., Murphy, M.C., Gould, B.J. and Williams, C.M. 1997. Use of manufactured foods enriched with fish oils as a means of increasing long-chain n3 polyunsaturated fatty acid intake. British Journal of Nutrition, 78: 223-236.

Martinez-Gonzalez, M.A., Garcia-Arellano, A., Toledo, E., Salas-Salvado, J., BuilCosiales, D., Covas, M.I., Schroder, H., Aros, F., Gomez-Gracia, E., Fiol, M., Ruiz-Gutierrez, V., Lapetra, J., LamuelaRaventos, R.M., Serra-Majem, L., Pinto, X., Munoz, M.A., Warnberg, J., Ros, E. and Estruch, R. 2012. A 14-item Mediterranean diet assessment tool and obesity indexes among high-risk subjects: the PREDIMED trial. PLoS One, 7(8): 43134-43137.

Mattijssen, F., Alex, S., Swarts, H.J., Groen, A.K., van Schothorst, E.M. and Kersten, S. 2014. Angptl4 serves as an endogenous inhibitor of intestinal lipid digestion. Molecular Metabolism, 3(2): 135-144.

Mazloom, K., Siddiqi, I. and Covasa, M. 2019. Probiotics: How Effective Are They in the Fight against Obesity? Nutrients, 11(2): 124.

Meadus, W., MacInnis, R. and Dugan, M. 2002. Prolonged dietary treatment with conjugated linoleic acid stimulates porcine muscle peroxisome proliferator activated receptor gamma and glutamine-fructose amino transferase gene expression in vivo. The Journal of Molecular Endocrinology, 28: 79-86.

Melanson, E., Astrup, A. and Danahoo, W. 2009. The relationship between dietary fat and fatty acid intake and body weight, diabetes and the metabolic syndrome. Annals of Nutrition and Metabolism, 55: 229-243.

Munro, I., Harwood, M., Hlywka, J., Stephen, A., Doull, J., Flamm, W. and Adlerereutz, H. 2003. Soy isoflavones: A safety review. Nutrition Reviews, 61: 1-33.

Murakami, K., Sasaki, S., Okubo, H., Takahashi, Y., Hosoi, Y. and Itabashi, M. 2007. Dietary fiber intake, dietary glycemic index and load and body mass index: A cross-sectional study of 3931 Japanese women aged 18-20 years. The European Journal of Clinical Nutrition, 61: 986-995.

Nagao, K. and Yanagita, T. 2005. Conjugated fatty acids in food and their health benefits. The Journal of Bioscience and Bioengineering, 100(2): 152-157.

Nielsen, N. S., Klein, A. and Jacobsen, C. 2009. Effect of ingredients on oxidative stability of fish oil-enriched drinking yogurt. European Journal of Lipid Science and Technology, 111: 337-345.

Nieuwdorp, M., Gilijamse, P., Pai, N. and Kaplan, L. 2014. Role of the microbiome in energy regulation and metabolism. Gastroenterology, 146(6): 1525-1533.

Obsen, T., Faergeman, N.j., Chung, S., Martinez, K., Gobern, S., Loreau, O., Wabitsch, M., Mandrup, S. and McIntosh, M. 2012. Trans-10, cis-12 conjugated linoleic acid decreases de novo lipid synthesis in human adipocytes. Journal of Nutritional Biochemistry, 23: 580-590.

Pal, S., Radavelli-Bagatini, S., Hagger, M. and Ellis, V. 2014. Comparative effects of whey and casein proteins on satiety in overweight and obese individuals: a randomized controlled trial. European Journal of Clinical Nutrition, 68(9): 980986.

Parekh, P.J., Arusi, E., Vinik, A. and Johnson, D. 2014. The role and influence of gut microbiota in pathogenesis and management of obesity and metabolic syndrome. Frontiers in Endocrinology, 5(47): 1-7.

Pe'russe, L. and Bouchard, C. 2000. Gene-diet interactions in obesity. American Society for Clinical Nutrition, 72: 1285S$1290 \mathrm{~S}$.

Pereira, M. and Ludwig, D. 2001. Dietary fiber 
and body-weight regulation: Observations and mechanisms. Pediatric Clinics of North America, 48: 969-980.

Plaza-Diaz, J., Ruiz-Ojeda, F., Gil-Campos, M. and Gil, A. 2019. Mechanisms of Action of Probiotics. Advances in Nutrition, 10(1): S49-S66.

Porcella, M.I., S'anchez, G., Vaudagna, S.R., Zanelli, M.L., Descalzo, A.M., Meichtri, L.H., Gallinger, M.M. and Lasta, J.A. 2001. Soy protein isolate added to vacuum-packaged chorizos: Effect on drip loss, quality characteristics and stability during refrigerated storage. Meat Science, 57: 437-443.

Rideout, T., Harding, S. and Jones, P. 2010. Consumption of plant sterols reduces plasma and hepatic triglycerides and modulates the expression of lipid regulatory genes and de novo lipogenesis in C57BL/6J mice. Molecular Nutrition \& Food Research, 54: S7-S13.

Rosenheck, R. 2008. Fast food consumption and increased caloric intake: a systematic review of a trajectory towards weight gain and obesity risk. Obesity Reviews, 9(6): 535-547.

Rossi, E.A., Cavallini, D.C.V., Carlos, I.Z., Vendramini, R.C., D^amaso, A.R. and de Valdez, G.F. 2008. Intake of isoflavonesupplemented soy yogurt fermented with Enterococcus faecium lowers serum total cholesterol and non-HDL cholesterol of hypercholesterolemic rats. European Food Research and Technology, 228: 275-282.

Santos, N.W., Yoshimura, E.H., Machado, E., Matumoto-Pintro, P.T., Montanher, P.F., Visentainer, J.V., dos Santos, G.T. and Zeoula, L.M. 2016. Antioxidant effects of a propolis extract and vitamin $\mathrm{E}$ in blood and milk of dairy cows fed diet containing flaxseed oil. Livestock Science, 191: 132138.

Santos, N.W., Yoshimura, E.H., Mareze-Costa, C.E., Machado, E., Agustinho, B.C., Pereira, L.M., Brito, M.N., Brito, N.A. and Zeoula, L.M. 2017. Supplementation of cow milk naturally enriched in polyunsaturated fatty acids and polyphenols to growing rats. PloS one, 12(3), e0172909.
Sarker, M. and Rahman, M.M. 2017. Dietary Fiber and Obesity Management. Advances in Obesity Weight Management \& Control, 7(3): 199-203.

Sendra, E., Fayos, P., Lario, Y., FernandezL'opez, J., Sayas-Barbera, E. and P'erezAlvarez, J.A. 2008. Incorporation of citrus fibers in fermented milk containing probiotic bacteria. Food Microbiology, 25(1): 13-21.

Serrano, J. and S'anchez Gonz'alez, I. 2008. Trends in functional foods against obesity: Functional ingredients, technologically modified foods and full diets. Revista Española de Nutrición Comunitaria, 14(3): 193-200.

Shi, H., DiRienzo, D. and Zemel, M.B. 2001. Effects of dietary calcium on adipocyte lipid metabolism and body weight regulation energy-restricted aP2-agouti transgenic mice. The FASEB journal, 15: 291-293.

Silveira, M., Carraro, R., Monereo, S. and T'ebar, J. 2007. Conjugated linoleic acid (CLA) and obesity. Public Health Nutrition, 10(10A): 1181-1186.

Sukkar, S.G., Vaccaro, A., Ravera, G.B., Borrini, C., Gradaschi, R., Sacchi-Nemours, A.M., Cordera, R. and Andraghetti, G. 2013. Appetite control and gastrointestinal hormonal behavior (CCK, GLP-1, PYY 136) following low doses of a whey protein-rich nutraceutic. Mediterranean Journal of Nutrition and Metabolism, 6(3): 259-266.

Sun, X. and Zemel, M.B. 2004. Role of uncoupling protein 2 (UCP2) expressions and $1 \alpha, 25$-dihydroxyvitamin D3 in modulating adipocyte apoptosis. The FASEB journal, 18(12): 1430-1432.

Suzuki, K., Konno, R., Shimizu, T., Nagashima, T. and Kimura, A. 2007. A fermentation product of phytosterol including campestenone reduces body fat storage and body weight gain in mice. Journal of Nutritional Science and Vitaminology, 53: 63-67.

Takeshita, M., Saito, S., Moriwaki, J., Takase, N., Shiiba, D., Kudo, N., Nakajima,Y. and Tokimitsu, I. 2007. Effects of dietary diacylglycerol oil containing phytosterols 
in mayonnaise on abdominal fat and blood cholesterol levels in Japanese men. Japanese Pharmacology \& Theraspeitis, 39: 973-987.

Thom, E., Wadstein, J. and Gudmundson, O. 2001. Conjugated linoleic acid reduces body fat in healthy exercising humans. The Journal of International Medical Research, 29: 392-396.

Trigueros, L., Pena, S., Ugidos, A.V., SayasBarberá, E., Pérez-Álvarez, J.A. and Sendra, E. 2013. Food ingredients as anti-obesity agents: A review. Critical Reviews in Food Science and Nutrition, 53(9): 929-942.

Turnbaugh, P., Ley, R., Mahowald, M., Magrini, V., Mardis, E. and Gordon, J. 2006. An obesity-associated gut microbiome with increased capacity for energy harvest. Nature, 444 (7122): 1027-1031.

Velasquez, M. and Bhathena, S. 2007. Role of dietary soy protein in obesity. International Journal of Medical Science, 4: 72-82.

Vij, S., Hati, S. and Yadav, D. 2011. Biofunctionality of probiotic soy yoghurt. Food and Nutrition Sciences, 2(5), 502509.

Vincent, R. and le Roux, C. 2007. New agents in development for the management of obesity. International Journal of Clinical Practice, 61(12): 2103-2112.

WHO (2018). Overweight and Obesity. Available at: https://www.who.int/news-room/factsheets/detail/obesity-and-overweight (accessed 25 September 2018).

Yep, Y.L., Li, D., Mann, N.J., Bode, O. and Sinclair, A.J. 2002. Bread enriched with microencapsulated tuna oil increases plasma docosahexaenoic acid and total omega-3 oils in humans. Asia Pacific journal of clinical nutrition, 11(4): 285291.

Zemel, M.B., Shi, H., Greer, B., DiRienzo, D. and Zemel, P.C. 2000. Regulation of adiposity by dietary calcium. The FASEB journal, 14: 1132-1138.

Zemel, M.B. 2002. Regulation of adiposity and obesity risk by dietary calcium: Mechanisms and implications. Journal of the American College of Nutrition, 21(2): 146S-151S.

Zemel, M.B. 2005. The role of dairy foods in weight management. Journal of the American College of Nutrition, 24(6): 537S-546S.

\section{How to cite this article:}

Piyush Limbachiya, Jayesh Kabariya, Dr. Tanmay Hazra and Dr. Vimal Ramani 2019. Effect of Natural Food Components to Reduce the Risk Of Obesity: A Review. Int.J.Curr.Microbiol.App.Sci. 8(09): 2506-2518. doi: https://doi.org/10.20546/ijcmas.2019.809.291 